\title{
In vitro effects of etanercept on the development of different $T$ cell subsets in patients with juvenile idiopathic arthritis
}

\author{
Rolando Cimaz*, Lorenzo Cosmi, Laura Maggi, Gabriele Simonini, Teresa Giani, Ilaria Pagnini, Veronica Santarlasci, \\ Manuela Capone, Valentina Querci, Francesco Liotta, Enrico Maggi, Francesco Annunziato
}

From 18th Pediatric Rheumatology European Society (PReS) Congress

Bruges, Belgium. 14-18 September 2011

\section{Background}

Recently, we found that CD4+CD161+ T lymphocytes showing transient nature of the Th17 phenotype are present in the synovial fluid of patients with JIA, and that their accumulation positively correlates with parameters of inflammation, supporting the hypothesis that these cells may play a role in disease activity.

\section{Aim \\ In the present study, we assessed the ability of etaner- cept to influence the in vitro development of different $\mathrm{T}$ cell subsets in JIA patients. In particular, we have evalu- ated the ability of peripheral blood (PB) and synovial fluid (SF) lymphocytes from patients followed in our Unit, to proliferate and produce cytokines in response to polyclonal (antiCD3/antiCD28) stimulation in pre- sence or in absence of etanercept.}

\section{Methods}

Lymphocytes from PB and SF have been cultured in the presence of etanercept $(5 \mu \mathrm{g} / \mathrm{ml})$, and proliferative responses were evaluated as thimidine uptake and $\%$ of bromodeoxyuridine positive cells. Cell phenotype by flow cytometry and cytokine production (\% of producing cells) in CD4+ cells were also assessed.

\section{Results}

We have initially studied 11 patients with oligoarticular or polyarticular JIA who underwent therapeutic arthrocentesis, with concomitant venipuncture for routine blood tests. Administration in culture of etanercept did not significantly affect the proliferative response to aCD3/aCD28

AOU Meyer and Careggi, Firenze, Italy

(C) 2011 Cimaz et al; licensee BioMed Central Ltd. This is an open access article distributed under the terms of the Creative Commons Attribution License (http://creativecommons.org/licenses/by/2.0), which permits unrestricted use, distribution, and reproduction in any medium, provided the original work is properly cited. stimulation of both PB- and SF-derived total CD4+ lymphocytes, whereas the presence in culture of etanercept increased the frequency of proliferating CD4+CD161+ lymphocytes. Accordingly, etanercept in vitro administration increased the frequency of total IL-17-producing CD4+ T cells, leaving the IFN-gamma-producing ones unaffected.

\section{Conclusions}

These in vitro preliminary results seem to indicate that etanercept is able to increase the frequency of IL-17 producing cells by favouring their proliferation.

Published: 14 September 2011

doi:10.1186/1546-0096-9-S1-P112

Cite this article as: Cimaz et al:: In vitro effects of etanercept on the development of different $T$ cell subsets in patients with juvenile idiopathic arthritis. Pediatric Rheumatology 2011 9(Suppl 1):P112.

Submit your next manuscript to BioMed Central and take full advantage of:

- Convenient online submission

- Thorough peer review

- No space constraints or color figure charges

- Immediate publication on acceptance

- Inclusion in PubMed, CAS, Scopus and Google Scholar

- Research which is freely available for redistribution 